[Chem. Pharm. Bull.

35( 4 )1405-1412(1987).

\title{
An Efficient, Regiospecific Synthesis of 4-Demethoxydaunomycinone and Daunomycinone
}

\author{
Yasumitsu Tamura, ${ }^{*}$ Manabu Sasho, Shuji Akai, \\ Hisakazu Kishimoto, Jun-IChI SeKihachi, \\ and YASUYUKI KITA
}

Faculty of Pharmaceutical Sciences, Osaka University, 1-6, Yamada-oka, Suita, Osaka 565, Japan

(Received September 25, 1986)

\begin{abstract}
4-Methoxy and 4-acetoxyhomophthalic anhydrides were prepared by convenient oxidations of homophthalic acid derivatives followed by hydrolysis and dehydrative cyclization. Strong baseinduced cycloaddition of these anhydrides to 2-chloro-6,6-ethylenedioxy-5,6,7,8-tetrahydro-1,4naphthoquinone gave the tetracyclic adducts, which were efficiently converted into 4-demethoxydaunomycinone and daunomycinone.
\end{abstract}

Keywords - anthracyclinone; 4-demethoxydaunomycinone; daunomycinone; cycloaddition; 4-methoxyhomophthalic anhydride; 4-acetoxyhomophthalic anhydride; ethynylcerium(III) 1,2addition reagent

The anthracycline antibiotics, daunomycin (1), adriamycin (2), and 4-demethoxydaunomycin (3), are clinically significant drugs for the treatment of a broad spectrum of human cancers. ${ }^{1}$ Efficient total synthesis of these anthracyclines, especially regiospecific preparation, has been the subject of intense study ${ }^{2)}$ due to the lack of an efficient biosynthetic process as well as the search for more active analogs with reduced cardiotoxicity. We have reported $^{3)}$ a regiocontrolled synthesis of the late-stage intermediates ( 7 and 8) to the anthracyclinones (4-6) using a strong base-induced cycloaddition of homophthalic anhydrides to 2-chloro-6,6-ethylenedioxy-5,6,7,8-tetrahydro-1,4-naphthoquinone as shown in Chart 1. Although this method is useful for the small-scale preparation of $\mathbf{7}$ and $\mathbf{8}$, the oxidation step of the cycloadducts $(\mathbf{9}$ and $\mathbf{1 0})$ to the para-acetoxylated products (11 and 12) with lead tetraacetate (LTA)/acetic acid-methylene chloride remains to be investigated since the yields are quite variable $(25-79 \%)$ depending on the reaction conditions, especially the purity of the reagent itself, the reaction temperature, and the scale of the reaction. We have previously communicated ${ }^{4)}$ a greatly improved synthesis of 7 and 8 by using the previously $\mathrm{C}_{4}$-acetoxylated homophthalic anhydrides (14 and 15) and an efficient conversion of 7 and 8 into 4 and $\mathbf{5}$. We present here a full account of the work as well as a demonstration of the synthetic utility of $\mathrm{C}_{4}$-oxygenated homophthalic anhydrides $(\mathbf{1 3}-\mathbf{1 5})$ for the preparation of key intermediates (7 and $\mathbf{8})$.

\section{Results and Discussion}

The requisite starting materials, 4-methoxy- (13) and 4-acetoxyhomophthalic anhydrides (14 and 15) were unknown in the literature. Since 2 '-oxygenated homophthalic acids seemed to be favorable starting materials for $13-15$, we first tried the introduction of some oxygen functions at the $\mathrm{C}_{2}$--position of dimethyl homophthalate followed by hydrolysis of the esters. Dimethyl homophthalate was converted into the ketene silyl acetal intermediate (i) with 
<smiles>[R2]CC(=O)[C@]1(O)Cc2c(O)c3c(c(O)c2[C@@H]([R9])C1)C(=O)c1c([R])cccc1C3=O</smiles>

$1: \mathrm{R}^{1}=\mathrm{OMe}, \mathrm{R}^{2}=\mathrm{H}, \mathrm{R}^{3}=$ daunosaminyl

$2: \mathrm{R}^{1}=\mathrm{OMe}, \mathrm{R}^{2}=\mathrm{OH}, \mathrm{R}^{3}=$ daunosaminyl

$3: \mathrm{R}^{1}=\mathrm{R}^{2}=\mathrm{H}, \mathrm{R}^{3}=$ daunosaminyl

4: $\mathrm{R}^{1}=\mathrm{R}^{2}=\mathrm{R}^{3}=\mathrm{H}$

$5: \mathrm{R}^{1}=\mathrm{OMe}, \mathrm{R}^{2}=\mathrm{R}^{3}=\mathrm{H}$

6: $\mathrm{R}^{1}=\mathrm{OMe}, \mathrm{R}^{2}=\mathrm{OH}, \mathrm{R}^{3}=\mathrm{H}$

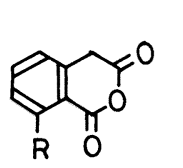

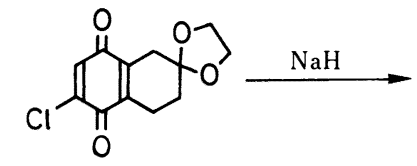<smiles>[R]c1cccc2cc3c(c(O)c12)C(=O)C1=C(CCC2(CC1)OCCO2)C3=O</smiles>

9: $\mathrm{R}=\mathrm{H}$

$10: \mathrm{R}=\mathrm{OMe}$

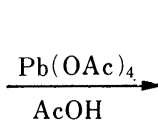

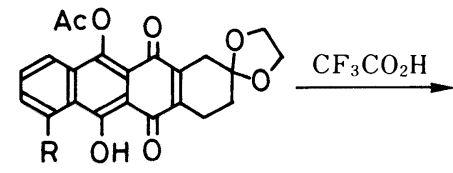

$11: \mathrm{R}=\mathrm{H}$

$12: \mathrm{R}=\mathrm{OMe}$

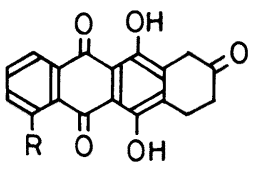

$7: \mathrm{R}=\mathrm{H}$

$8: \mathrm{R}=\mathrm{OMe}$

Chart 1

lithium diisopropylamide (LDA)/trimethylsilyl chloride, and (i) was oxidized with LTA $^{5)}$ or $m$-chloroperbenzoic acid $(m \text {-CPBA })^{6)}$ to give dimethyl $2^{\prime}$-acetoxy- $(16)$ or $2^{\prime}$-hydroxyhomophthalate (17) in $83 \%$ or $44 \%$ yield, respectively. $2^{\prime}$-Methoxylation was accomplished by the treatment of dimethyl homophthalate with $\mathrm{PhI}(\mathrm{OAc})_{2}$ [phenyl iodosyl diacetate, PIDA] in methanolic sodium methoxide to give a $50 \%$ yield of dimethyl $2^{\prime}$-methoxyhomophthalate (18). ${ }^{7)}$ Although hydrolysis of the ester (18) gave the desired $2^{\prime}$-methoxyhomophthalic acid (19), other esters (16 and 17) gave an unwanted product, phthalide-3-carboxylic acid (20) selectively on alkaline hydrolysis followed by careful acidification. After several unsuccessful attempts, ${ }^{8)}$ the 2 '-acetoxyhomophthalic acids ( 21 and 22 ) were successfully obtained from the homophthalic acids themselves by the most straightforward method: the homophthalic acids were treated with 3.2 eq of LDA in tetrahydrofuran (THF) and quenched with trimethylsilyl chloride to give the ketene silyl acetal intermediates (ii), which were oxidized with LTA in benzene to give quantitatively the corresponding $2^{\prime}$-acetoxyhomophthalic acids. These acids $\left(\mathbf{1 9}, \mathbf{2 1}\right.$, and 22) were treated with 1.3 eq of trimethylsilylethoxyacetylene ${ }^{9)}$ in methylene chloride to give, in quantitative yields, the 4-methoxy-(13) and 4-acetoxyhomophthalic anhydrides (14 and 15), respectively.

Conversion of the anhydrides $(\mathbf{1 3}-\mathbf{1 5})$ to the tetracyclic adducts $(\mathbf{2 3}-\mathbf{2 5})$ was carried out by our strong base-induced cycloaddition method. ${ }^{3)}$ Treatment of the sodium salts generated from these anhydrides and 1.0-1.1 eq of $\mathrm{NaH}$ in THF with 2-chloro-6,6ethylenedioxy-5,6,7,8-tetrahydro-1,4-naphthoquinone at room temperature gave the regiospecific naphthacenediones $(23-25)$ in $65 \%, 72 \%$, and $62 \%$ yields, respectively. The latter two adducts ( 24 and $\mathbf{2 5}$ ) were identical with authentic samples prepared earlier by us ${ }^{3 b}$ ) and were readily hydrolyzed quantitatively to 7 and $\mathbf{8}$ with $80 \%$ trifluoroacetic acid. The former adduct was assigned as $\mathbf{2 3}$ on the basis of spectral evidence and the following chemical 

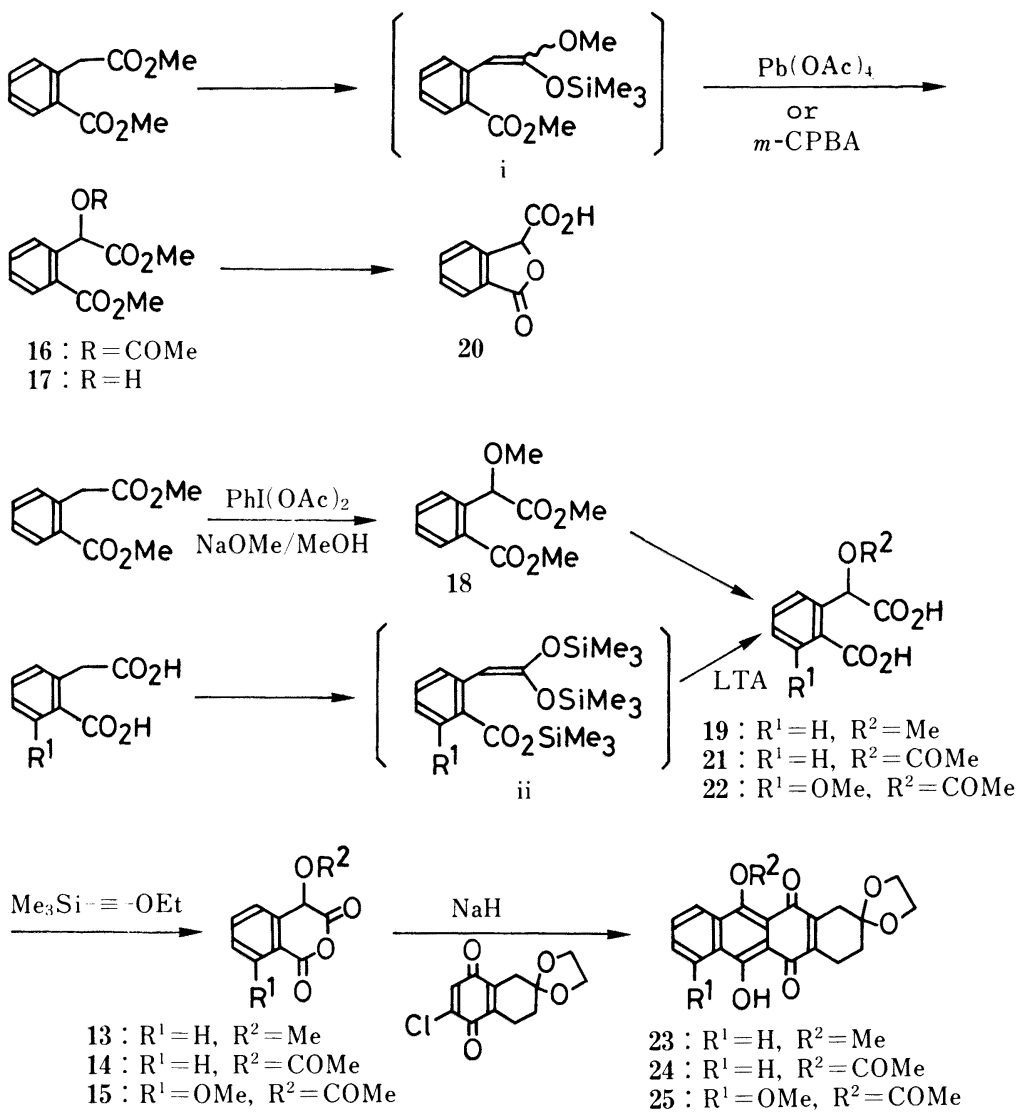

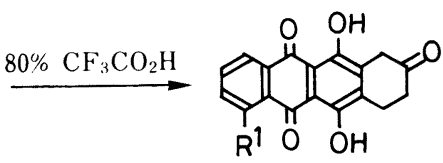

$7: \mathrm{R}^{1}=\mathrm{H}$

$8: \mathrm{R}^{1}=\mathrm{OMe}$
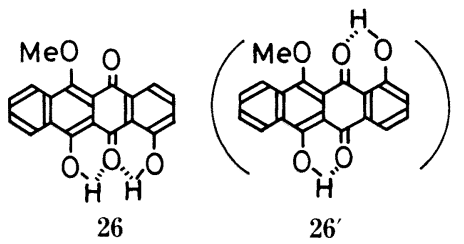

Chart 2

behavior: hydrolysis of $\mathbf{2 3}$ with $80 \%$ trifluoroacetic acid gave a quantitative yield of $\mathbf{7}$ and the regiochemistry of the cycloaddition of 4-methoxyhomophthalic anhydride (13) was shown to have the same orientation as that of the 4-acetoxyhomophthalic anhydrides (14 and 15) in the reaction with 3-bromo-5-hydroxy-1,4-naphthoquinone, giving the single adduct (26) [not the regioisomer $\left.26^{\prime}\right]^{10)}$ As shown above, the use of $\mathrm{C}_{4}$-acetoxyhomophthalic anhydrides $(\mathbf{1 4}$ and 15) instead of homophthalic anhydrides was found to be the best method for the preparation of 7 and 8.

As for the side-chain elaboration of the 9-keto group of these tetracyclic ketones ( 7 and 8), there remains the need for some improvements since the reported side-chain elaboration of the 9 -keto group by using ethynylmagnesium bromide gives inadequate yields. ${ }^{11)}$ All other existing methodologies for the homologation of $\mathbf{7}$ and $\mathbf{8}$ using acyl anion equivalents were tried but did not give satisfactory results, probably due to the ready base-catalyzed enolization of the 9-keto group. Recently, we have found ${ }^{12)}$ that trimethylsilylethynylcerium (III) reagent is quite useful for the conversion of an enolizable ketone into a hydroxyacetone moiety and we 


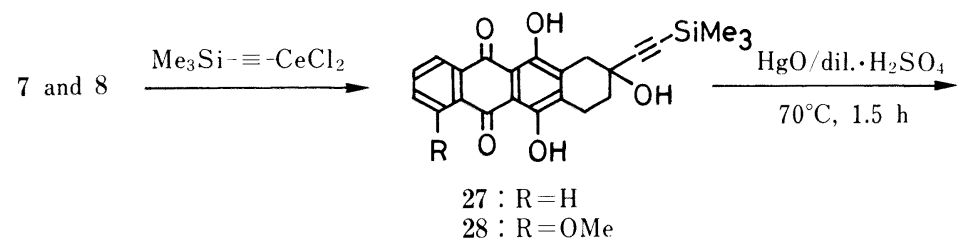<smiles>[R]c1cccc2c1C(=O)c1c(O)c3c(c(O)c1C2=O)CC(O)(C(C)=O)CC3</smiles>

$29: \mathrm{R}=\mathrm{H}$

$30: \mathrm{R}=\mathrm{OMe}$

AIBN = azobisisobutyronitrile

Chart 3

successfully applied this method for the conversion of $\mathbf{7}$ and $\mathbf{8}$ to the 9-hydroxyacetone compounds. ${ }^{13,14)}$ Trimethylsilylethynylation of the tetracyclic ketones ( 7 and $\mathbf{8}$ ) with 20 eq of trimethylsilylethynylcerium (III) chloride [prepared from trimethylsilylethynyllithium and cerium (III) chloride in THF] at $-78^{\circ} \mathrm{C}$ for $3 \mathrm{~h}$ gave the 9-trimethylsilylethynyl alcohols ( 27 and 28) in $77 \%$ and $69 \%$ yields, respectively. Direct transformation of a 2 -trimethylsilylethynyl group into a methyl ketone was readily accomplished by a standard method using mercury (II) ion: treatment of the trimethylsilylethynyl alcohols (27 and 28) with $\mathrm{HgO} / \mathrm{dil} . \mathrm{H}_{2} \mathrm{SO}_{4}$ in refluxing THF gave the 9-hydroxyacetone compounds (29 and 30 ) in $87 \%$ and $86 \%$ yields, respectively. As conversion of $\mathbf{2 9}$ or $\mathbf{3 0}$ into $\mathbf{4}$ or $\mathbf{5}$ by convenient methods has already been described, ${ }^{11,15)}$ our approach constitutes a highly convergent synthesis of $\mathbf{4}$ and $\mathbf{5}$.

\section{Experimental}

All melting points are uncorrected. Infrared (IR) absorption spectra were recorded on a JASCO HPIR-102 spectrometer and proton nuclear magnetic resonance $\left({ }^{1} \mathrm{H}-\mathrm{NMR}\right)$ spectra on a Hitachi R-20A $(60 \mathrm{MHz})$, a Hitachi R$22(90 \mathrm{MHz})$, or a JEOL JNM-FX $90 \mathrm{Q}(90 \mathrm{MHz})$ spectrometer (with tetramethylsilane as an internal standard). Lowand high-resolution mass spectra (MS) were obtained with a JEOL JMS D-300 instrument, with a direct inlet system at $70 \mathrm{eV}$. Column chromatography was carried out on Merck Silica gel 60 .

Methyl 2-Acetoxy-2-(2-methoxycarbonylphenyl)acetate (16) - A solution of $n$-BuLi $(1.6 \mathrm{~N}, 0.75 \mathrm{ml}, 1.2 \mathrm{mmol})$ was added dropwise under nitrogen to a stirred solution of dry diisopropylamine $(0.17 \mathrm{ml}, 1.2 \mathrm{mmol})$ in anhydrous THF $(3 \mathrm{ml})$ at $0 \mathrm{C}$. The mixture was stirred for a few minutes under the same conditions and then used as a THF solution of LDA. A solution of dimethyl homophthalate $(208 \mathrm{mg}, 1.0 \mathrm{mmol})$ in anhydrous THF $(3 \mathrm{ml})$ was added dropwise to the solution of $\mathrm{LDA}$ over a few minutes at $-78{ }^{\circ} \mathrm{C}$ and $\mathrm{Me}_{3} \mathrm{SiCl}(0.25 \mathrm{ml}, 2.0 \mathrm{mmol})$ was added to the mixture. The whole was stirred at $-78^{\circ} \mathrm{C}$ for $2 \mathrm{~h}$, allowed to warm to room temperature, and stirred for $30 \mathrm{~min}$. The reaction mixture was concentrated under reduced pressure and pentane $(6 \mathrm{ml})$ was added to the residue. The mixture was filtered rapidly and the filtrate was concentrated in vacuo to give the ketene silyl acetal intermediate (i) $(282 \mathrm{mg}$, approximately $100 \%$ ), which was used in the next oxidation reaction without purification. A solution of the ketene silyl acetal (i) $(140 \mathrm{mg}$, approximately $0.5 \mathrm{mmol})$ in dry benzene $(2 \mathrm{ml})$ was added to a stirred suspension of LTA ( $247 \mathrm{mg}, 0.5 \mathrm{mmol})$ in dry benzene $(3 \mathrm{ml})$ at room temperature under nitrogen. The resulting slurry was stirred for $2 \mathrm{~h}$ under the same conditions and filtered to remove lead (II) acetate. The filtrate was poured into $5 \% \mathrm{HCl}(15 \mathrm{ml})$, and extracted with ether $(15 \mathrm{ml} \times 2)$. The extract was washed with brine, dried over $\mathrm{MgSO}_{4}$, and concentrated in vacuo to give a residue, which was subjected to column chromatography on silica gel with hexane : ethyl acetate $=5: 1$ as the

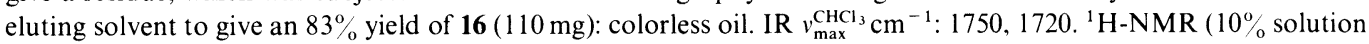
in $\left.\mathrm{CDCl}_{3}\right) \delta: 2.17(\mathrm{~s}, 3 \mathrm{H}, \mathrm{OCOMe}), 3.72\left(\mathrm{~s}, 3 \mathrm{H}, \mathrm{CO}_{2} \mathrm{Me}\right), 3.91\left(\mathrm{~s}, 3 \mathrm{H}, \mathrm{CO}_{2} \mathrm{Me}\right), 7.07\left(\mathrm{~s}, 1 \mathrm{H},-\mathrm{C}_{-} \mathrm{HCO}_{2} \mathrm{Me}\right), 7.5-7.55$ (m, 3H, ArH), 7.9-7.95 (m, 1H, ArH). Anal. Calcd for $\mathrm{C}_{13} \mathrm{H}_{14} \mathrm{O}_{6}: \mathrm{C}, 58.64 ; \mathrm{H}, 5.30$. Found: C, 58.81; H, 5.04.

Methyl 2-Hydroxy-2-(2-methoxycarbonylphenyl)acetate (17) A solution of the ketene silyl acetal (i) $(840 \mathrm{mg}$, approximately $3 \mathrm{mmol})$, prepared by the procedure described above, in dry hexane $(10 \mathrm{ml})$ was added to a stirred suspension of $m$-CPBA $(80 \%, 647 \mathrm{mg}, 3.0 \mathrm{mmol})$ in dry hexane $(10 \mathrm{ml})$ at $0{ }^{\circ} \mathrm{C}$ under nitrogen. The resulting slurry was stirred at room temperature for $30 \mathrm{~min}$ and filtered. The filtrate was worked up in the same manner as described 


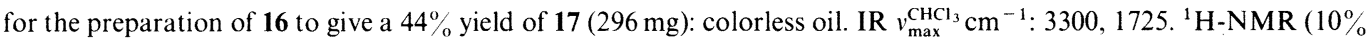
solution in $\left.\mathrm{CDCl}_{3}\right) \delta: 3.48\left(\mathrm{~s}, 3 \mathrm{H}, \mathrm{CO}_{2} \mathrm{Me}\right), 3.71\left(\mathrm{~s}, 3 \mathrm{H}, \mathrm{CO}_{2} \mathrm{Me}\right), 5.97\left(\mathrm{~s}, 1 \mathrm{H}, \mathrm{CHCO}_{2} \mathrm{Me}\right), 7.1-7.8(\mathrm{~m}, 4 \mathrm{H}, \mathrm{ArH})$. The 2-hydroxy ester (17) was acetylated with $\mathrm{Ac}_{2} \mathrm{O}$-pyridine to give the acetate (16), which was identical with a sample obtained from dimethyl homophthalate.

Methyl 2-Methoxy-2-(2-methoxycarbonylphenyl)acetate (18) Dimethyl homophthalate (208 $\mathrm{mg}, 1.0 \mathrm{mmol})$ was added to a stirred solution of $\mathrm{Na}(76 \mathrm{mg}, 3.3 \mathrm{mmol})$ in dry $\mathrm{MeOH}(3 \mathrm{ml})$ at room temperature under nitrogen. The mixture was stirred for a few minutes under the same conditions and $\mathrm{C}_{6} \mathrm{H}_{5} \mathrm{I}(\mathrm{OAc})_{2}(483 \mathrm{mg}, 1.5 \mathrm{mmol})$ was added. The resulting slurry was stirred at room temperature for $4 \mathrm{~d}$, poured into $10 \%$ hydrochloric acid, made neutral, and extracted with $\mathrm{CH}_{2} \mathrm{Cl}_{2}(10 \mathrm{ml} \times 3)$. The extract was washed with brine, dried over $\mathrm{Na}_{2} \mathrm{SO}_{4}$, and concentrated in vacuo. The residue was subjected to column chromatography on silica gel with hexane:ethyl

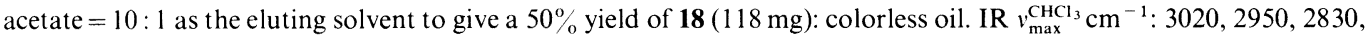
1740, 1720, 1600, 1580. ${ }^{1} \mathrm{H}-\mathrm{NMR}\left(10 \%\right.$ solution in $\left.\mathrm{CDCl}_{3}\right) \delta: 3.47(\mathrm{~s}, 3 \mathrm{H}, \mathrm{OMe}), 3.70\left(\mathrm{~s}, 3 \mathrm{H}, \mathrm{CO}_{2} \mathrm{Me}\right), 3.90(\mathrm{~s}, 3 \mathrm{H}$, $\mathrm{CO}_{2} \mathrm{Me}$ ), $5.80\left(\mathrm{~s}, 1 \mathrm{H},-\mathrm{C}_{-1 C O} \mathrm{Me}\right), 7.3-7.6(\mathrm{~m}, 3 \mathrm{H}, \mathrm{ArH}) 7.8-8.0(\mathrm{~m}, 1 \mathrm{H}, \mathrm{ArH})$. Exact MS Calcd for $\mathrm{C}_{12} \mathrm{H}_{14} \mathrm{O}_{5}$ : 238.0841. Found: 238.0846

2-Methoxy-2-(2-carboxyphenyl)acetic Acid (19) - A solution of $\mathbf{1 8}(150 \mathrm{mg}, 0.63 \mathrm{mmol})$ in $7 \%$ aqueous $\mathrm{KOH}$ $(4 \mathrm{ml})$ and $\mathrm{MeOH}(2 \mathrm{ml})$ was heated at reflux for $3 \mathrm{~h}$. The mixture was concentrated in vacuo and partitioned between ether $(15 \mathrm{ml})$ and water $(5 \mathrm{ml})$. The solution was adjusted to $\mathrm{pH} 1$ by addition of conc. $\mathrm{HCl}$ and extracted with ether. The aqueous layer was saturated with $\mathrm{NaCl}$ and extracted with ether $(30 \mathrm{ml} \times 3)$. The combined extract was washed with brine, dried over $\mathrm{MgSO}_{4}$, and concentrated in vacuo to give an $89 \%$ yield of $\mathbf{1 9}(117 \mathrm{mg})$. Recrystallization from ethyl acetate gave a pure sample as colorless crystals; mp $148-149^{\circ} \mathrm{C}$. Anal. Calcd for $\mathrm{C}_{10} \mathrm{H}_{10} \mathrm{O}_{5}$ : C, 57.14; $\mathrm{H}, 4.80$. Found: C, 56.95; H, 4.75 .

3-Phthalidecarboxylic Acid (20)_-1) From 16: A solution of $16(180 \mathrm{mg}, 0.68 \mathrm{mmol})$ in $30 \%$ aqueous $\mathrm{NaOH}$ $(3 \mathrm{ml})$ and $\mathrm{MeOH}(3 \mathrm{ml})$ was heated at reflux for $2 \mathrm{~h}$. The reaction mixture was worked up as described for the preparation of 19 to give a quantitative yield $(120 \mathrm{mg})$ of $\mathbf{2 0}$. Recrystallization from ethyl acetate gave a pure sample: mp 151-153 C (lit. ${ }^{16)} 149-150 \mathrm{C}$ ). IR $v_{\max }^{\mathrm{KCl}} \mathrm{cm}^{-1}: 2850,1770,1710 .{ }^{1} \mathrm{H}-\mathrm{NMR}$ (acetone- $\left.d_{6}\right) \delta: 6.11(\mathrm{~s}, 1 \mathrm{H}, \mathrm{CH})$, $7.75-7.85(\mathrm{~m}, 4 \mathrm{H}, \mathrm{ArH})$.

2) From 17: The ester (17) $(152 \mathrm{mg}, 0.68 \mathrm{mmol})$ was treated with $30 \%$ aqueous $\mathrm{NaOH}$ under the conditions described above (1) to give a $96 \%$ yield $(115 \mathrm{mg})$ of $\mathbf{2 0}$, which was identical with an authentic sample obtained from 16.

2-Acetoxy-2-(2-carboxyphenyl)acetic Acid (21)_A solution of homophthalic acid (180 $\mathrm{mg}, 1.0 \mathrm{mmol})$ in dry THF $(3 \mathrm{ml})$ was added dropwise to a solution of LDA $(3.2 \mathrm{mmol})$ in THF over a few minutes at $-78^{\circ} \mathrm{C}$ under nitrogen and the mixture was stirred for $30 \mathrm{~min}$ under the same conditions. After addition of $\mathrm{Me}_{3} \mathrm{SiCl}(0.75 \mathrm{ml}$, $5.9 \mathrm{mmol}$ ), the reaction mixture was stirred at $-78^{\circ} \mathrm{C}$ for $1.5 \mathrm{~h}$, allowed to warm to room temperature, and stirred for an additional $30 \mathrm{~min}$. Work-up in the same manner as described for the preparation of $\mathbf{1 6}$ gave the ketene silyl acetal intermediate (ii), which was used in the next oxidation reaction without purification. A solution of the ketene silyl acetal (ii) in dry benzene ( $4 \mathrm{ml})$ was added to a stirred suspension of LTA $(550 \mathrm{mg}, 1.12 \mathrm{mmol})$ in dry benzene ( $3 \mathrm{ml})$ at room temperature under nitrogen. The resulting slupry was worked up in the same manner as described for the preparation of $\mathbf{1 6}$ to give a quantitative yield $(238 \mathrm{mg})$ of $\mathbf{2 1}$. Recrystallization from ethyl acetate-hexane gave a pure sample; mp $148-150 \mathrm{C}$. IR $v_{\max }^{\mathrm{KCl}} \mathrm{cm}^{-1}: 3070 \mathrm{sh}, 3020 \mathrm{sh}, 2920,2850,2630,1755,1720,1675,1600,1580 .{ }^{1} \mathrm{H}-\mathrm{NMR}$ (acetone- $d_{6}$ ) $\delta: 2.12(\mathrm{~s}, 3 \mathrm{H}, \mathrm{OCOMe}), 6.80\left(\mathrm{br} \mathrm{s}, 2 \mathrm{H}, \mathrm{CO}_{2} \mathrm{H} \times 2\right), 7.18\left(\mathrm{~s}, 1 \mathrm{H},-\mathrm{CHCO}_{2} \mathrm{H}\right), 7.2-7.8(\mathrm{~m}, 3 \mathrm{H}, \mathrm{ArH})$, 7.9-8.15 (m, 1H, ArH). Anal. Calcd for $\mathrm{C}_{11} \mathrm{H}_{10} \mathrm{O}_{6}: \mathrm{C}, 55.46 ; \mathrm{H}, 4.23$. Found: C, 55.39; H, 4.29.

2-Acetoxy-2-(2-carboxy-3-methoxyphenyl)acetic Acid (22) According to the same procedure as described for the preparation of $\mathbf{2 1}$, a $97 \%$ yield $(261 \mathrm{mg})$ of $\mathbf{2 2}$ was obtained from 2-carboxy-3-methoxyphenylacetic acid $(210 \mathrm{mg}$,

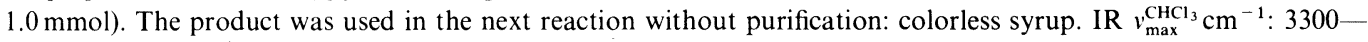
$2800,1760-1710 .{ }^{1} \mathrm{H}-\mathrm{NMR}$ (acetone- $\left.d_{6}\right) \delta: 2.09$ (s, 3H, OCOMe), $3.87(\mathrm{~s}, 3 \mathrm{H}, \mathrm{OMe}), 6.21\left(\mathrm{~s}, 1 \mathrm{H},-\mathrm{CHCO}_{2} \mathrm{H}\right), 6.30$ (brs, $2 \mathrm{H}, \mathrm{CO}_{2} \mathrm{H} \times 2$ ), 6.95-7.55 (m, 3H, ArH). Exact MS Calcd for $\mathrm{C}_{12} \mathrm{H}_{12} \mathrm{O}_{7}: 268.0580$. Found: 268.0574.

4-Methoxyhomophthalic Anhydride (13) - A solution of $19(115 \mathrm{mg}, 0.55 \mathrm{mmol})$ and trimethylsilylethoxyacetylene $(116 \mathrm{mg}, 0.82 \mathrm{mmol})$ in dry $\mathrm{CH}_{2} \mathrm{Cl}_{2}(2 \mathrm{ml})$ was stirred at $40^{\circ} \mathrm{C}$ for $3.5 \mathrm{~h}$. After removal of insoluble material by filtration, the filtrate was concentrated in vacuo to give a $92 \%$ yield $(97 \mathrm{mg})$ of 13 . Recrystallization from $\mathrm{CH}_{2} \mathrm{Cl}_{2-}$ hexane gave a pure sample as colorless crystals; $\mathrm{mp} 122-125^{\circ} \mathrm{C}$. IR $v_{\max }^{\mathrm{CHCl}_{3}} \mathrm{~cm}^{-1}: 1805,1765,1605 .{ }^{1} \mathrm{H}-\mathrm{NMR}\left(10^{\circ}\right.$ solution in $\left.\mathrm{CDCl}_{3}\right) \delta: 3.76(\mathrm{~s}, 3 \mathrm{H}, \mathrm{OMe}), 5.17(\mathrm{~s}, 1 \mathrm{H}, \mathrm{CH}), 7.5-7.85(\mathrm{~m}, 3 \mathrm{H}, \mathrm{ArH}), 8.05-8.25(\mathrm{~s}, 1 \mathrm{H}, \mathrm{ArH})$. Anal. Calcd for $\mathrm{C}_{10} \mathrm{H}_{8} \mathrm{O}_{4} \cdot \mathrm{H}_{2} \mathrm{O} ; \mathrm{C}, 57.14 ; \mathrm{H}, 4.80$. Found: $\mathrm{C}, 57.17 ; \mathrm{H}, 4.78$.

4-Acetoxyhomophthalic Anhydride (14) A solution of $21(80 \mathrm{mg}, 0.34 \mathrm{mmol})$ and trimethylsilylethoxyacetylene $(65 \mathrm{mg}, 0.46 \mathrm{mmol})$ in dry $\mathrm{CH}_{2} \mathrm{Cl}_{2}(1.5 \mathrm{ml})$ was stirred at room temperature for $4 \mathrm{~h}$. Concentration of the

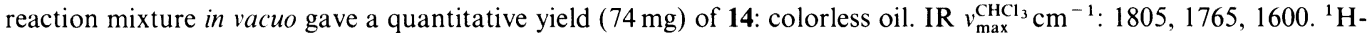
$\operatorname{NMR}\left(10 \%\right.$ solution in $\left.\mathrm{CDCl}_{3}\right) \delta: 2.31(\mathrm{~s}, 3 \mathrm{H}, \mathrm{OCOMe}), 6.53(\mathrm{~s}, 1 \mathrm{H}, \mathrm{CH}), 7.3-7.9(\mathrm{~m}, 3 \mathrm{H}, \mathrm{ArH}), 8.05-8.3(\mathrm{~m}, 1 \mathrm{H}$, ArH), MS $m / z: 220\left(\mathrm{M}^{+}\right)$. Exact MS Calcd for $\mathrm{C}_{11} \mathrm{H}_{8} \mathrm{O}_{5}: 220.0369$. Found: 220.0351 .

4-Acetoxy-8-methoxyhomophthalic Anhydride (15) A solution of $22(80 \mathrm{mg}, 0.30 \mathrm{mmol})$ and trimethylsilylethoxyacetylene $(65 \mathrm{mg}, 0.46 \mathrm{mmol})$ in dry $\mathrm{CH}_{2} \mathrm{Cl}_{2}(1.5 \mathrm{ml})$ was stirred at room temperature for $4 \mathrm{~h}$. Concentration of the reaction mixture in vacuo gave a quantitative yield $(74 \mathrm{mg})$ of 15 . Recrystallization from benzene-hexane gave a 
pure sample: mp $162-164 \mathrm{C}$. IR $v_{\max }^{\mathrm{CHCl}_{3}} \mathrm{~cm}^{-1}: 1815,1765,1600 .{ }^{1} \mathrm{H}-\mathrm{NMR}\left(10 \%\right.$ solution in $\left.\mathrm{CDCl}_{3}\right) \delta: 2.32(\mathrm{~s}, 3 \mathrm{H}$, OCOMe), $4.00(\mathrm{~s}, 3 \mathrm{H}, \mathrm{OMe}), 6.51(\mathrm{~s}, 1 \mathrm{H}, \mathrm{CH}), 6.9-7.2(\mathrm{~m}, 2 \mathrm{H}, \mathrm{ArH}), 7.70(\mathrm{t}, 1 \mathrm{H}, J=7.5 \mathrm{~Hz}, \mathrm{ArH}), \mathrm{MS} m / z: 250$ $\left(\mathrm{M}^{+}\right)$. Anal. Calcd for $\mathrm{C}_{12} \mathrm{H}_{10} \mathrm{O}_{6}: \mathrm{C}, 57.60 ; \mathrm{H}, 4.03$. Found: $\mathrm{C}, 57.27 ; \mathrm{H}, 4.01$.

General Procedure for the Cycloaddition of Homophthalic Anhydrides (13-15) to 2-Chloro-6,6-ethylenedioxy5,6,7,8-tetrahydro-1,4-naphthoquinone Leading to Cycloadducts (23-25) - A mixture of the anhydride (0.5 mmol) and $\mathrm{NaH}(60 \%$ in mineral oil, $0.55 \mathrm{mmol})$ in anhydrous THF $(2 \mathrm{ml})$ was stirred at room temperature for several minutes under nitrogen, then a solution of the quinone $(0.5 \mathrm{mmol})$ in anhydrous THF $(4 \mathrm{ml})$ was added. The reaction mixture was stirred at room temperature for a suitable period (checked by thin layer chromatography (TLC)), then quenched with saturated aqueous $\mathrm{NH}_{4} \mathrm{Cl}(20 \mathrm{ml})$ and extracted with $\mathrm{CH}_{2} \mathrm{Cl}_{2}(20 \mathrm{ml} \times 3)$. The extract was washed with brine, dried over $\mathrm{Na}_{2} \mathrm{SO}_{4}$, and concentrated in vacuo. The residue was subjected to column chromatography on silica gel with $\mathrm{CHCl}_{3}$ : ether $=30: 1$ as the eluting solvent to give the corresponding adduct.

2, 2-Ethylenedioxy-6-hydroxy-11-methoxy-1, 2, 3, 4-tetrahydronaphthacene-5, 12-dione (23) ——This was prepared from $13(45 \mathrm{mg}, 0.23 \mathrm{mmol})$ and 2-chloro-6,6-ethylenedioxy-5,6,7,8-tetrahydro-1,4-naphthoquinone (59 $\mathrm{mg}$, $0.23 \mathrm{mmol}$ ) at room temperature for $3 \mathrm{~h}$ in a $65 \%$ yield $(55 \mathrm{mg})$. Recrystallization from benzene gave a pure

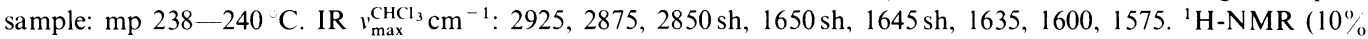
solution in $\left.\mathrm{CDCl}_{3}\right) \delta: 1.91\left(\mathrm{t}, 2 \mathrm{H}, J=7 \mathrm{~Hz}, \mathrm{CH}_{2}\right), 2.7-3.1\left(\mathrm{~m}, 4 \mathrm{H}, \mathrm{CH}_{2} \times 2\right), 4.00\left(\mathrm{~s}, 4 \mathrm{H}, \mathrm{OCH}_{2} \mathrm{CH}_{2} \mathrm{O}\right), 4.05(\mathrm{~s}, 3 \mathrm{H}$ OMe), 7.6-7.9 (m, 2H, ArH), 8.2-8.6 (m, 2H, ArH), $14.80(\mathrm{~s}, 1 \mathrm{H}, \mathrm{OH})$. Anal. Calcd for $\mathrm{C}_{21} \mathrm{H}_{18} \mathrm{O}_{6}: \mathrm{C}, 68.84 ; \mathrm{H}$, 4.95. Found: C, 68.94; H, 4.80.

11-Acetoxy-2,2-ethylenedioxy-6-hydroxy-1,2,3,4-tetrahydronaphthacene-5, 12-dione (24)-This was prepared from $14(74 \mathrm{mg}, 0.34 \mathrm{mmol})$ and 2-chloro-6,6-ethylenedioxy-5,6,7,8-tetrahydro-1,4-naphthoquinone $(86 \mathrm{mg}$, $0.34 \mathrm{mmol})$ at room temperature for $18 \mathrm{~h}$ in a $75 \%$ yield $(99 \mathrm{mg})$. Recrystallization from $\mathrm{CH}_{2} \mathrm{Cl}_{2}-\mathrm{MeOH}_{\text {gave }}$ a pure sample: $\mathrm{mp} 225-228^{\circ} \mathrm{C}$ (lit. ${ }^{3 \text { b) }} 215-217^{\circ} \mathrm{C}$ ). This was identical with an authentic sample.

11-Acetoxy-2,2-ethylenedioxy-6-hydroxy-7-methoxy-1,2,3,4-tetrahydronaphthacene-5, 12-dione (25)-This was prepared from $15(86 \mathrm{mg}, 0.34 \mathrm{mmol})$ and 2-chloro-6, 6-ethylenedioxy-5, 6, 7,8-tetrahydro-1, 4-naphthoquinone $(87 \mathrm{mg}, 0.34 \mathrm{mmol})$ at room temperature for $15 \mathrm{~h}$ in a $62 \%$ yield $(90 \mathrm{mg})$. Recrystallization from $\mathrm{CH}_{2} \mathrm{Cl}_{2}-\mathrm{EtOH}$ gave a pure sample: $\mathrm{mp} 244.5-246^{\circ} \mathrm{C}$ (lit. ${ }^{3 b)} 244.5-246 \mathrm{C}$ ). This was identical with an authentic sample.

1,11-Dihydroxy-6-methoxynaphthacene-5,12-dione (26)_-A solution of 3-bromo-5-hydroxy-1,4-naphthoquinone $(16 \mathrm{mg}, 0.06 \mathrm{mmol})$ in anhydrous THF $(1 \mathrm{ml})$ was added to a stirred suspension of $13(13 \mathrm{mg}, 0.07 \mathrm{mmol})$ and $\mathrm{NaH}(60 \%$ in mineral oil, $8 \mathrm{mg}, 0.20 \mathrm{mmol})$ in anhydrous THF $(2 \mathrm{ml})$ at room temperature under nitrogen. The reaction mixture was stirred for $2 \mathrm{~h}$ under the same conditions, then quenched with saturated aqueous $\mathrm{NH}_{4} \mathrm{Cl}(10 \mathrm{ml})$. The aqueous layer was adjusted to $\mathrm{pH} 2$ by addition of $1 \mathrm{~N} \mathrm{HCl}$ and extracted with $\mathrm{CH}_{2} \mathrm{Cl}_{2}(15 \mathrm{ml} \times 3)$. The extract was washed with brine, dried over $\mathrm{MgSO}_{4}$, and concentrated in vacuo. The residue was subjected to preparative TLC on silica gel with benzene $:$ hexane $=4: 1$ as the developing solvent to give a $77 \%$ yield $(16 \mathrm{mg})$ of 26 . Recrystallization

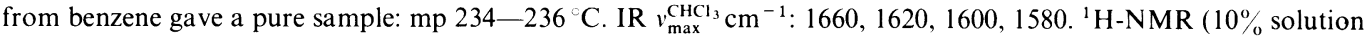
in $\left.\mathrm{CDCl}_{3}\right) \delta: 4.07(\mathrm{~s}, 3 \mathrm{H}, \mathrm{OMe}), 7.25(\mathrm{dd}, 1 \mathrm{H}, J=8,1.5 \mathrm{~Hz}, \mathrm{ArH}), 7.55-8.0(\mathrm{~m}, 4 \mathrm{H}, \mathrm{ArH}), 8.3-8.6(\mathrm{~m}, 2 \mathrm{H}, \mathrm{ArH})$, $12.22(\mathrm{~s}, 1 \mathrm{H}, \mathrm{OH}), 14.40(\mathrm{~s}, 1 \mathrm{H}, \mathrm{OH})$. Exact $\mathrm{MS}$ Calcd for $\mathrm{C}_{19} \mathrm{H}_{12} \mathrm{O}_{5}: 320.0683$. Found: 320.0665.

6,11-Dihydroxy-7,8-dihydronaphthacene-5,9(10H), 12-trione (7)-1) From 23: A solution of $23(20 \mathrm{mg}$, $0.055 \mathrm{mmol})$ in $\mathrm{CF}_{3} \mathrm{CO}_{2} \mathrm{H}(4 \mathrm{ml})$ and water $(1 \mathrm{ml})$ was heated at $50{ }^{\circ} \mathrm{C}$ for $2 \mathrm{~h}$, then concentrated in vacuo, and the residue was partitioned between $\mathrm{CH}_{2} \mathrm{Cl}_{2}(10 \mathrm{ml})$ and water. The aqueous layer was extracted with $\mathrm{CH}_{2} \mathrm{Cl}_{2}(20 \mathrm{ml} \times 2)$. The combined extract was washed with brine, dried over $\mathrm{Na}_{2} \mathrm{SO}_{4}$, and concentrated in vacuo. The residue was subjected to column chromatography on silica gel with $\mathrm{CHCl}_{3}$ : ethyl acetate $=20: 1$ as the eluting solvent to give a quantitative yield $(17 \mathrm{mg})$ of 7 . Recrystallization from $\mathrm{CH}_{2} \mathrm{Cl}_{2}-\mathrm{MeOH}$ gave a pure sample: mp over $300^{\circ} \mathrm{C}$, (lit. ${ }^{3 \text { ) }}$ 296-298 ${ }^{\circ}$, lit. ${ }^{17)} 300{ }^{\circ} \mathrm{C}$ ). This was identical with an authentic sample.

2) From 24: The experimental details were as reported. ${ }^{3 b)}$

6,11-Dihydroxy-4-methoxy-7,8-dihydronaphthacene-5,9(10H), 12-trione (8) - The experimental details were as reported. ${ }^{3 b)}$

6,9,11-Trihydroxy-9-(2-trimethylsilylethynyl)-7, 8,9, 10-tetrahydronaphthacene-5, 12-dione (27)-—The $\mathrm{CeCl}_{3}-\mathrm{Me}_{3} \mathrm{Si}-\equiv-\mathrm{Li}$ reagent system was used with a modification of the reported method. ${ }^{18)}$ Anhydrous cerium chloride $\left(\mathrm{CeCl}_{3}, 370 \mathrm{mg}, 1.5 \mathrm{mmol}\right)$ was placed in a two-necked flask, heated in vacuo $(0.1 \mathrm{mmHg})$ at $140^{\circ} \mathrm{C}$ for $2 \mathrm{~h}$ and then cooled. Dry THF $(3 \mathrm{ml})$ was added under nitrogen, stirring was continued for $1 \mathrm{~h}$, and the flask was cooled to $-78^{\circ} \mathrm{C}$. Then lithium trimethylsilylacetylide [prepared from trimethylsilylacetylene $(0.21 \mathrm{ml}, 1.5 \mathrm{mmol})$ and $n$ $\operatorname{BuLi}(1.6 \mathrm{~N}, 0.61 \mathrm{ml}, 0.97 \mathrm{mmol})$ in dry THF $(2 \mathrm{ml})$ at $-40^{\circ} \mathrm{C}$ for $30 \mathrm{~min}$ ] was added to the cooled suspension with stirring. The mixture was stirred at $-78^{\circ} \mathrm{C}$ for $1 \mathrm{~h}$ and then used as a THF solution of trimethylsilylethynylcerium (III) chloride. To this solution was added a solution of $7(20 \mathrm{mg}, 0.065 \mathrm{mmol})$ in dry THF (3 ml) at $-78^{\circ} \mathrm{C}$ under nitrogen. The mixture was stirred for $2 \mathrm{~h}$ under the same conditions and then quenched with water $(15 \mathrm{ml})$, made acidic by addition of dil. $\mathrm{HCl}$, and extracted with $\mathrm{CH}_{2} \mathrm{Cl}_{2}(30 \mathrm{ml} \times 2)$. The extract was washed with brine, dried over $\mathrm{MgSO}_{4}$, and concentrated in vacuo. The residue was purified by column chromatography on silica gel with $\mathrm{CHCl}_{3}$ : ethyl acetate $=100: 1$ as the eluting solvent to give a $77 \%$ yield $(21 \mathrm{mg})$ of 27 as a red solid. Recrystallization

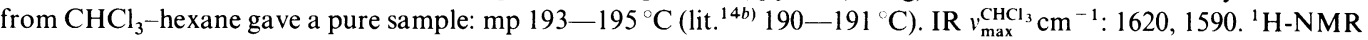
$\left(10 \%\right.$ solution in $\left.\mathrm{CDCl}_{3}\right) \delta: 0.17\left(\mathrm{~s}, 9 \mathrm{H}, \mathrm{SiMe}_{3}\right), 2.12\left(\mathrm{brt}, 2 \mathrm{H}, J=6.0 \mathrm{~Hz}, \mathrm{CH}_{2}\right), 2.29(\mathrm{br} \mathrm{s}, 1 \mathrm{H}, \mathrm{OH}), 2.97(\mathrm{brt}, 2 \mathrm{H}$, 
$\left.J=6.0 \mathrm{~Hz}, \mathrm{CH}_{2}\right), 3.13\left(\mathrm{brs}, 2 \mathrm{H}, \mathrm{CH}_{2}\right), 7.7-7.9(\mathrm{~m}, 2 \mathrm{H}, \mathrm{ArH}), 8.2-8.35(\mathrm{~m}, 2 \mathrm{H}, \mathrm{ArH}), 13.35(\mathrm{~s}, 1 \mathrm{H}, \mathrm{OH}), 13.36(\mathrm{~s}$, $1 \mathrm{H}, \mathrm{OH})$. Exact MS Calcd for $\mathrm{C}_{23} \mathrm{H}_{22} \mathrm{O}_{5} \mathrm{Si}: 406.1234$. Found: 406.1218 .

6,9,11-Trihydroxy-4-methoxy-9-(2-trimethylsilylethynyl)-7,8,9,10-tetrahydronaphthacene-5, 12-dione (28)According to the same procedure as described for the preparation of 27 , a $69 \%$ yield $(19.5 \mathrm{mg})$ of 28 was obtained from trimethylsilylacetylene $(0.21 \mathrm{ml}, 1.5 \mathrm{mmol}), n$-BuLi $(1.6 \mathrm{~N}, 0.61 \mathrm{ml}, 0.97 \mathrm{mmol})$, anhydrous $\mathrm{CeCl}_{3}(370 \mathrm{mg}$, $1.5 \mathrm{mmol})$ and $8(22 \mathrm{mg}, 0.065 \mathrm{mmol})$ as a red solid. Recrystallization from $\mathrm{CHCl}_{3}$ gave a pure sample: $\mathrm{mp} 262-$ $264.5^{\circ} \mathrm{C}$. IR $v_{\max }^{\mathrm{CHCl}_{3}} \mathrm{~cm}^{-1}: 1605,1580 .{ }^{1} \mathrm{H}-\mathrm{NMR}\left(10 \%\right.$ solution in $\left.\mathrm{CDCl}_{3}\right) \delta: 0.19\left(\mathrm{~s}, 9 \mathrm{H}, \mathrm{SiMe}_{3}\right), 2.0-2.2\left(\mathrm{~m}, 3 \mathrm{H}, \mathrm{CH}_{2}\right.$ and $\mathrm{OH}), 3.02\left(\mathrm{brt}, 2 \mathrm{H}, J=6.0 \mathrm{~Hz}, \mathrm{CH}_{2}\right), 3.15\left(\mathrm{br} \mathrm{s}, 2 \mathrm{H}, \mathrm{CH}_{2}\right), 4.10(\mathrm{~s}, 3 \mathrm{H}, \mathrm{OMe}), 7.37(\mathrm{dd}, 1 \mathrm{H}, J=8.5,1.0 \mathrm{~Hz}, \mathrm{ArH})$, $7.76(\mathrm{t}, 1 \mathrm{H}, J=8.5 \mathrm{~Hz}, \mathrm{ArH}), 8.04(\mathrm{dd}, 1 \mathrm{H}, J=8.5,1.0 \mathrm{~Hz}, \mathrm{ArH}), 13.48(\mathrm{~s}, 1 \mathrm{H}, \mathrm{OH}), 13.85(\mathrm{~s}, 1 \mathrm{H}, \mathrm{OH})$. Exact MS Calcd for $\mathrm{C}_{24} \mathrm{H}_{24} \mathrm{O}_{6} \mathrm{Si}: 436.1339$. Found: 436.1322 .

9-Acetyl-6,9,11-trihydroxy-7,8,9,10-tetrahydronaphthacene-5, 12-dione (4-Demethoxy-7-deoxydaunomycinone) (29)-A solution of 27 (13 mg, $0.032 \mathrm{mmol}), \mathrm{HgO}(21 \mathrm{mg}, 0.097 \mathrm{mmol})$, and $20 \% \mathrm{H}_{2} \mathrm{SO}_{4}(0.5 \mathrm{ml})$ in THF (2 ml) was heated at reflux for $1.5 \mathrm{~h}$ and then cooled to room temperature. The reaction mixture was diluted with $0.5 \% \mathrm{HCl}$ $(10 \mathrm{ml})$ and extracted with $\mathrm{CH}_{2} \mathrm{Cl}_{2}(15 \mathrm{ml} \times 3)$. The extract was washed with brine, dried over $\mathrm{MgSO}_{4}$, and concentrated in vacuo. The residue was purified by column chromatography on silica gel with $\mathrm{CHCl}_{3}$ :ethyl acetate $=50: 1$ as the eluting solvent to give an $87 \%$ yield $(9.8 \mathrm{mg})$ of 29 as a red solid. Recrystallization from $\mathrm{CH}_{2} \mathrm{Cl}_{2-}$ $n$-hexane gave a pure sample: $\mathrm{mp} 211-213.5^{\circ} \mathrm{C}$ (lit. ${ }^{14 a)} 212.5-214.5^{\circ} \mathrm{C}$, lit. ${ }^{11 b)} 160-162^{\circ} \mathrm{C}$, lit. $\left.{ }^{19 a}\right) 210-212^{\circ} \mathrm{C}$,

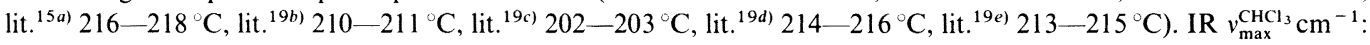
$1705,1615,1585 .{ }^{1} \mathrm{H}-\mathrm{NMR}\left(10 \%\right.$ solution in $\left.\mathrm{CDCl}_{3}\right) \delta: 1.85-2.1\left(\mathrm{~m}, 2 \mathrm{H}, \mathrm{CH}_{2}\right), 2.40(\mathrm{~s}, 3 \mathrm{H}, \mathrm{COMe}), 2.9-3.15(\mathrm{~m}$, $\left.4 \mathrm{H}, \mathrm{CH}_{2} \times 2\right), 3.79(\mathrm{~s}, 1 \mathrm{H}, \mathrm{OH}), 7.75-7.9(\mathrm{~m}, 2 \mathrm{H}, \mathrm{ArH}), 8.2-8.45(\mathrm{~m}, 2 \mathrm{H}, \mathrm{ArH}), 13.43(\mathrm{~s}, 2 \mathrm{H}, \mathrm{OH} \times 2) . \mathrm{MS} m / z: 352$ $\left(\mathrm{M}^{+}\right)$.

9-Acetyl-6,9, 11-trihydroxy-4-methoxy-7,8,9,10-tetrahydronaphthacene-5, 12-dione (7-Deoxydaunomycinone) (30) - According to the same procedure as described for the preparation of 29, an $86 \%$ yield $(6.6 \mathrm{mg})$ of 30 was obtained from $28(8.8 \mathrm{mg}, 0.02 \mathrm{mmol}), \mathrm{HgO}(13 \mathrm{mg}, 0.06 \mathrm{mmol})$, and $20 \% \mathrm{H}_{2} \mathrm{SO}_{4}(0.3 \mathrm{ml})$ as a red solid. Recrystallization from ethyl acetate-THF gave a pure sample: mp $229-233.5^{\circ} \mathrm{C}$ (lit. ${ }^{20 a}$ ) $229-231^{\circ} \mathrm{C}$, lit. ${ }^{15 b)} 230-$

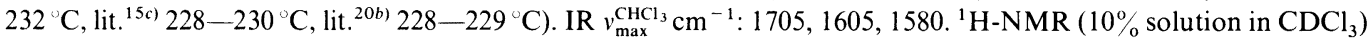
$\delta: 1.85-2.1\left(\mathrm{~m}, 2 \mathrm{H}, \mathrm{CH}_{2}\right), 2.38(\mathrm{~s}, 3 \mathrm{H}, \mathrm{COMe}), 2.8-3.2\left(\mathrm{~m}, 4 \mathrm{H}, \mathrm{CH}_{2} \times 2\right), 3.78(\mathrm{~s}, 1 \mathrm{H}, \mathrm{OH}), 4.08(\mathrm{~s}, 3 \mathrm{H}, \mathrm{OMe}), 7.36$ (br d, $1 \mathrm{H}, J=8.0 \mathrm{~Hz}, \mathrm{ArH}), 7.74(\mathrm{t}, 1 \mathrm{H}, J=8.0 \mathrm{~Hz}, \mathrm{ArH}), 8.02(\mathrm{brd}, 1 \mathrm{H}, J=8.0 \mathrm{~Hz}, \mathrm{ArH}), 13.43(\mathrm{~s}, 1 \mathrm{H}, \mathrm{OH}), 13.87(\mathrm{~s}$, $1 \mathrm{H}, \mathrm{OH}) . \mathrm{MS} m / z: 382\left(\mathrm{M}^{+}\right)$.

Acknowledgement We thank Mr. Fumio Fukata for technical assistance.

\section{References and Notes}

1) F. Arcamone, Lloydia, 40, 45 (1977); idem, "Topics in Antibiotic Chemistry," Vol. 2, ed. by P. G. Sammes, Ellis Horwood, Chichester, England, 1978, pp. 99-239; idem, "Doxorubicin Anticancer Antibiotics," Academic Press, in Medicinal Chemistry, Vol. 17, New York, 1981, p. 207, 212, 272, 287, 338; M. B. Naff, J. Plowman, and V. L. Narayanan, “Anthracycline Antibiotics,” ed. by H. S. ElKhadem, Academic Press, New York, 1982, pp. 1-57; T. Oki and T. Takeuchi, Yuki Gosei Kagaku Kyokai Shi, 40, 2 (1982).

2) T. R. Kelly, Ann. Rep. Med. Chem., 14, 288 (1979); W. A. Remers, "The Chemistry of Antitumor Antibiotics," Vol. 1, Chapter 2, Wiley-Interscience, Somerset, NJ, 1979, pp. 63-132; S. Terashima, Yuki Gosei Kagaku Kyokai Shi, 40, 20 (1982); Tetrahedron Symposia-in-Print Number 17, "Recent Aspects of Anthracyclinone Chemistry," ed. by T. R. Kelly, Tetrahedron, 40, 4539-4793 (1984).

3) a) Y. Tamura, A. Wada, M. Sasho, K. Fukunaga, H. Maeda, and Y. Kita, J. Org. Chem., 47, 4376 (1982); b) Y. Tamura, M. Sasho, S. Akai, A. Wada, and Y. Kita, Tetrahedron, 40, 4539 (1984); c) Y. Tamura, M. Sasho, K. Nakagawa, T. Tsugoshi, and Y. Kita, J. Org. Chem., 49, 473 (1984).

4) Y. Tamura, M. Sasho, S. Akai, H. Kishimoto, J. Sekihachi, and Y. Kita, Tetrahedron Lett., 27,195 (1986).

5) Introduction of an $\alpha$-OAc group into esters with LTA via ketene silyl acetals, see: G. M. Rubottom, J. M. Gruber, R. Marrero, H. D. Juve, Jr., and C. W. Kim, J. Org. Chem., 48, 4940 (1983) and references cited therein.

6) Introduction of an $\alpha$-OH group into esters with $m$-CPBA via ketene silyl acetals, see: $\mathrm{G}$. M. Rubottom and R. Marrero, Synth. Commun., 11, 505 (1981); R. Z. Andriamialisoa, N. Langlois, and Y. Langlois, J. Org. Chem., 50, 961 (1985).

7) Oxidation of dimethyl homophthalate under standard conditions using PIDA or phenyl iodosyl bis(trifluoroacetate) (PIFA)/KOH-MeOH gave a complex mixture accompanied with a small amount of 18 . Hypervalent iodine oxidation of carbonyl compounds, see: R. M. Moriarty and H. Hu, Tetrahedron Lett., 22, 2747 (1981); Y. Tamura, T. Yakura, H. Terashi, J. Haruta, and Y. Kita, Chem. Pharm. Bull., 35, 570 (1987) and references cited therein.

8) Attempts to use the benzyl ester failed.

9) This is an excellent reagent for the preparation of carboxylic anhydrides under mild conditions, see: Y. Kita, S. Akai, M. Yoshigi, Y. Nakajima, H. Yasuda, and Y. Tamura, Tetrahedron Lett., 25, 6027 (1984); Y. Kita, S. 
Akai, N. Ajimura, M. Yoshigi, T. Tsugoshi, H. Yasuda, and Y. Tamura, J. Org. Chem., 51, 4150 (1986).

10) The possibility of the isomeric structure $\left(\mathbf{2 6}^{\prime}\right)$ was readily ruled out from the characteristic non hydrogenbonded quinone absorption band in its IR spectrum.

11) a) A. S. Kende, Y.-g. Tsay, and J. E. Mills, J. Am. Chem. Soc., 98, 1967 (1976); b) A. S. Kende, D. P. Curran, Y.-g. Tsay, and J. E. Mills, Tetrahedron Lett., 1977, 3537.

12) Y. Tamura, M. Sasho, H. Ohe, S. Akai, and Y. Kita, Tetrahedron Lett., 26, 1549 (1985).

13) While this work was in progress, a similar elaboration method for 7 was reported by Terashima. ${ }^{14)}$ The weakly basic alkylcerium(III) reagents were shown to have greater nucleophilicity than the parent organolithium reagents by Imamoto et al., see: T. Imamoto, T. Kusumoto, and M. Yokoyama, J. Chem. Soc., Chem. Commun., 1982, 1042; T. Imamoto, Y. Sugiura, and N. Takiyama, Tetrahedron Lett., 25, 4233 (1984); T. Imamoto, Y. Tawarayama, T. Kusumoto, and M. Yokoyama, Yuki Gosei Kagaku Kyokai Shi, 42, 143 (1984); T. Imamoto, N. Takiyama, and K. Nakamura, Tetrahedron Lett., 26, 4763 (1985).

14) a) M. Suzuki, Y. Kimura, and S. Terashima, Chem. Lett., 1984, 1543; b) Idem, Chem. Pharm. Bull., 34, 1531 (1986).

15) a) K. Krohn and K. Tolkiehn, Chem. Ber., 112, 3453 (1979); b) T. H. Smith, A. N. Fujiwara, W. W. Lee, H. Y. Wu, and D. W. Henry, J. Org. Chem., 42, 3653 (1977); c) R. J. Blade and P. Hodge, J. Chem. Soc., Chem. Commun., 1979, 85; d) K. Ravichandran, F. A. J. Kerdesky, and M. P. Cava, J. Org. Chem., 51, 2044 (1986).

16) H. Inouye, T. Okuda, Y. Hirata, N. Nagakura, and M. Yoshizaki, Chem. Pharm. Bull., 15, 786 (1967); S. Ruhemann, J. Chem. Soc., 97, 2025 (1910).

17) D. N. Gupta, P. Hodge, and N. Khan, J. Chem. Soc., Perkin Trans. 1, 1981, 689.

18) T. Imamoto, T. Kusumoto, Y. Tawarayama, Y. Sugiura, T. Mita, Y. Hatanaka, and M. Yokoyama, J. Org. Chem., 49, 3904 (1984).

19) a) J. R. Wiseman, N. I. French, R. K. Hallmark, and K. G. Chiong, Tetrahedron Lett., 1978, 3765; b) M. J. Broadhurst, C. H. Hassall, and G. J. Thomas, J. Chem. Soc., Perkin Trans. 1, 1982, 2239; c) D. Domínguez, R. J. Ardecky, and M. P. Cava, J. Am. Chem. Soc., 105, 1608 (1983); d) S. Terashima, K. Tamoto, and M. Sugimori, Tetrahedron Lett., 23, 4107 (1982); Y. Kimura, M. Suzuki, T. Matsumoto, R. Abe, and S. Terashima, Chem. Lett., 1984, 473; e) M. Suzuki, T. Matsumoto, R. Abe, Y. Kimura, and S. Terashima, ibid., 1985, 57.

20) a) R. D: Gleim, S. Trenbeath, R. S. D. Mittal, and C. J. Sih, Tetrahedron Lett., 1976, 3385; F. Suzuki, S. Trenbeath, R. D. Gleim, and C. J. Sih, J. Org. Chem., 43, 4159 (1978); b) M. J. Broadhurst and C. H. Hassall, J. Chem. Soc., Perkin Trans. 1, 1982, 2227. 